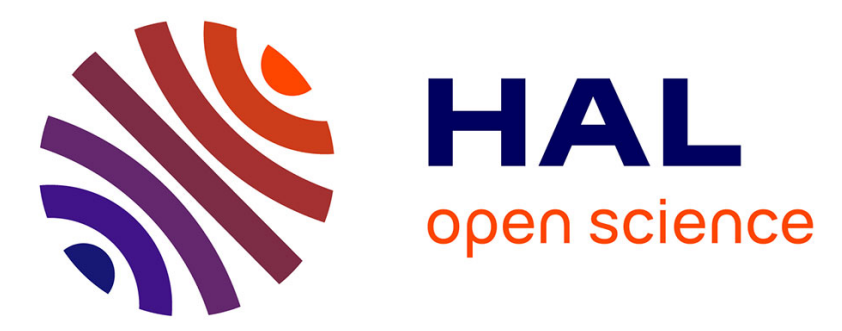

\title{
Influence of the halogen atom on the solid-state fluorescence properties of 2-phenyl-benzoxazole derivatives
}

\author{
A. Ghodbane, Nathalie Saffon, Sylvie Blanc, Suzanne Fery-Forgues
}

\section{To cite this version:}

A. Ghodbane, Nathalie Saffon, Sylvie Blanc, Suzanne Fery-Forgues. Influence of the halogen atom on the solid-state fluorescence properties of 2-phenyl-benzoxazole derivatives. Dyes and Pigments, 2015, 113, pp.219-226. 10.1016/j.dyepig.2014.08.011 . hal-01458708

\section{HAL Id: hal-01458708 \\ https://hal.science/hal-01458708}

Submitted on 9 Feb 2021

HAL is a multi-disciplinary open access archive for the deposit and dissemination of scientific research documents, whether they are published or not. The documents may come from teaching and research institutions in France or abroad, or from public or private research centers.
L'archive ouverte pluridisciplinaire HAL, est destinée au dépôt et à la diffusion de documents scientifiques de niveau recherche, publiés ou non, émanant des établissements d'enseignement et de recherche français ou étrangers, des laboratoires publics ou privés. 


\section{Influence of the halogen atom in the solid-state fluorescence properties of 2-phenyl-benzoxazole derivatives}

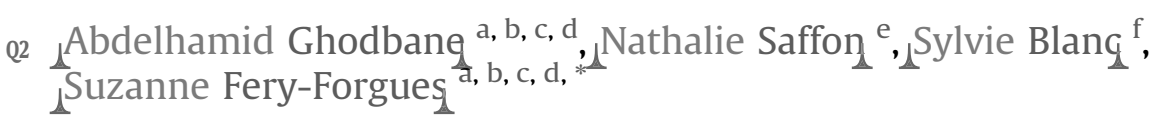

Q1 a CNRS, ITAV-USR 3505, F31106 Toulouse, France

${ }^{\mathrm{b}}$ Université de Toulouse, ITAV-USR 3505, F31106 Toulouse, France

c CNRS, IMRCP-UMR 5623, F31062 Toulouse, France

${ }^{\mathrm{d}}$ Université de Toulouse, IMRCP-UMR 5623, F31062 Toulouse, France

e Service commun RX, Institut de Chimie de Toulouse, ICT-FR2599, Université Paul Sabatier, 31062 Toulouse Cedex 9, France

${ }^{\mathrm{f}}$ Université de Pau et des Pays de l'Adour, IPREM-UMR 5254, F64053 Pau Cedex 9, France

\section{A R T I C L E I N F O}

Article history:

Received 25 June 2014

Received in revised form

31 July 2014

Accepted 11 August 2014

Available online $\mathrm{xxx}$

Keywords:

2-Phenyl-benzoxazole

Solid-state fluorescence

Photoluminescence

Crystal structure

Heavy atom effect

Reprecipitation

\begin{abstract}
A B S T R A C T
Four halogenated derivatives of 2-phenyl-benzoxazole and the unsubstituted analog were studied in solution and as powders by absorption and steady-state fluorescence spectroscopy. In solution, the fluorescence quantum yield was progressively decreased when increasing the size of the halogen atom, as explained by heavy atom effect. In the solid state, an increase in photoluminescence efficiency was observed when passing from the fluorinated to chlorinated derivative, and then the fluorescence efficiency was decreased for the brominated and iodinated derivatives, the latter compound being virtually not emissive. To explain the solid-state behavior, the influence of molecular arrangement on the emission properties was discussed on the basis of X-ray data. Finally, microcrystals were generated using a solvent-exchange method. An evolution from elongated platelets to cubic particles was observed with increasing the size of the halogen atom, providing preliminary information for the use of these compounds as micro- and nano-materials.
\end{abstract}

๑) 2014 Published by Elsevier Ltd.

\section{Introduction}

Organic fluorescent nanocrystals and non-doped nanoparticles are an emerging class of materials with great potential in the fields of biological sensing and imaging [1,2], organic optoelectronics $[3,4]$ and nanophotonic devices [5,6], including solid-state lasers. A prerequisite to their development is the selection of appropriate dyes, which could circumvent the general problem of aggregationcaused quenching $[7,8]$. In fact, although numerous organic dyes are strongly fluorescent in dilute solution, only very few of them emit efficiently in the solid state. This behavior is generally attributed to intermolecular interactions that provide non-radiative decay routes. The plane-to-plane stacking of fluorophores, which generates detrimental intermolecular coupling of the transition dipole moments, is the most common cause of the loss of emission

\footnotetext{
* Corresponding author. Institut des Technologies Avancées en sciences du Vivant (ITAV), CNRS USR 3035, Centre Pierre Potier, Oncopole, BP 50624, 31106 Toulouse Cedex 1, France. Tel.: +33582991035.

E-mail address: suzanne.fery-forgues@itav.fr (S. Fery-Forgues).
}

in the solid state. To increase the chances of developing highly fluorescent materials, a strategy is to work with the rare families of dyes that are not prone to plane-to-plane stacking. This is the case for the $4^{\prime}$-alkyl and $4^{\prime}$-alkoxy derivatives of 2-phenyl-benzoxazole [9] and naphthoxazole [10] that exhibit an original packing mode and display excellent fluorescence properties in the crystalline state. Our recent study revealed that small variations in the nature of the substituent borne by the phenyl ring lead to substantial changes in the spectroscopic and self-association properties. This observation prompted us to replace the hydrocarbon substituent by a halogen atom in the 2-phenyl-benzoxazole series. To our knowledge, the influence of the halogen atom on photoluminescence properties has not been subject to comprehensive and systematic study. The 2-phenyl-benzoxazole family seemed to be a good candidate to undertake this type of investigation.

Four derivatives of 2-phenyl-benzoxazole, bearing fluorine (1), chlorine (2), bromine (3) and iodine (4) atoms in the $4^{\prime}$-position were considered (Fig. 1). The photophysical and photochemical behaviors of these compounds were previously reported to depend on the electronegative character and size of the halogen atom [11-13]. For instance, the tendency to form photodimers was only 


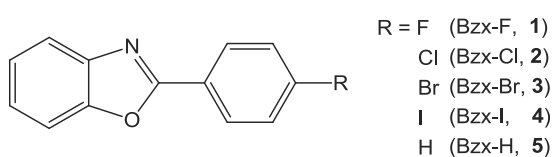

Fig. 1. Chemical structure of the 2-phenyl-benzoxazole derivatives 1-5.

observed for the first two members of the series [11,12], as it was also the case for the unsubstituted compound, while the brominated and iodinated derivatives tended to lose their halogen atom via homolytic photocleavage [11]. From a photophysical viewpoint, the fluorescence efficiency in cyclohexane was found to decrease in the order $\mathbf{1}>\mathbf{2}>\mathbf{3}>\mathbf{4}$. Differences were dramatic: emission of the fluorinated compound $\mathbf{1}$ was very strong, but almost totally quenched in 4 [11]. This effect was attributed to a heavy atom effect that enhances the probability of intersystem crossing [14]. Due to its good optical properties, the fluorinated compound $\mathbf{1}$ has been considered in view of applications as scintillating agent [15]. When used as a chelating agent, it has given highly luminescent iridiu$\mathrm{m}(\mathrm{III})$ complexes, ideal for OLED applications [16], and this has also been the case for the chlorinated compound 2 [17]. In contrast, the brominated and iodinated compounds $\mathbf{3}$ and $\mathbf{4}$ have been mainly used as synthesis intermediates to access antiviral drugs [18] and graft the benzoxazole rings on fluorescently labeled nucleotides [19] and organic semiconductors for light-emitting devices [20,21]. To the best of our knowledge, no information was available about the solid-state fluorescence properties of halogenated 2-phenylbenzoxazoles not involved in metal complexation. It seemed instructive to know if the compounds were emissive in the solid state, and if photoluminescence emission followed the same trend than in solution. As a matter of fact, it was expected that the heavy atom effect governed the photoluminescence properties. However, the halogen atoms could also introduce variations in the crystal packing mode, and there was no indication about how these variations may influence solid-state emission.

The present work firstly reports the fluorescence properties of the four halogenated compounds dissolved in organic solvents, and then the photoluminescence properties of the powder compounds. A comparison was made with unsubstituted compound $\mathbf{5}$ that was partially studied elsewhere [9]. The solid-state optical properties were discussed on the basis of the molecular arrangement of the five compounds, obtained by X-ray analysis. The possibility to access microparticles using a simple solvent-exchange method was also investigated because this approach may guide subsequent applications as micro- and nano-materials.

\section{Experimental}

\subsection{Materials}

Absolute ethanol and cyclohexane (Prolabo-VWR), as well as $n$ heptane (SDS) were used for spectroscopic work. The 2-phenylbenzoxazole derivatives $\mathbf{1}-\mathbf{5}$ were synthesized according to the general synthesis procedure described in ref. [9]. After recrystallization in methanol, they were obtained with a yield of $76 \%-90 \%$. Subsequent purification was then performed. Every compound was refluxed for $30 \mathrm{~min}$ in tetrahydrofuran in the presence of activated charcoal (12-20 mesh), the hot solution was filtered, half of the solvent was evaporated and the compound crystallized in the medium upon cooling after addition of methanol. The obtained compounds were perfectly white. They were characterized by usual methods. ${ }^{1} \mathrm{H}$ NMR, ${ }^{13} \mathrm{C}$ NMR and IR spectra were in good agreement with literature data [22-25]. The characteristics of 5 are given in ref. [9].

\subsubsection{2-(4'-Fluorophenyl)-benzoxazole (1)}

Yield: 76\%. Mp: $103.8{ }^{\circ} \mathrm{C} .{ }^{1} \mathrm{H} \mathrm{NMR}\left(\mathrm{CDCl}_{3}\right), \delta \mathrm{ppm}=8.29(\mathrm{dd}, 2 \mathrm{H}$, ${ }^{3} J_{\mathrm{H}-\mathrm{H}}=9 \mathrm{~Hz},{ }^{4} \mathrm{~J}_{\mathrm{H}-\mathrm{F}}=6 \mathrm{~Hz}, \mathrm{H}_{2^{\prime}}$ and $\left.\mathrm{H}_{6^{\prime}}\right) ; 7.82-7.79\left(\mathrm{~m}, 1 \mathrm{H}, \mathrm{H}_{7}\right)$; $7.63-7.58\left(\mathrm{~m}, 1 \mathrm{H}, \mathrm{H}_{4}\right) ; 7.42-7.36\left(\mathrm{~m}, 2 \mathrm{H}, \mathrm{H}_{5}\right.$ and $\left.\mathrm{H}_{6}\right) ; 7.26(\mathrm{dd}, 2 \mathrm{H}$, ${ }^{3} J_{\mathrm{H}-\mathrm{H}}=9 \mathrm{~Hz},{ }^{3} J_{\mathrm{H}-\mathrm{F}}=6 \mathrm{~Hz}, \mathrm{H}_{3^{\prime}}$ and $\left.\mathrm{H}_{5^{\prime}}\right) .{ }^{1} \mathrm{H}\left\{{ }^{19} \mathrm{~F}\right\}$ NMR $(300 \mathrm{MHz}$, $\left.\mathrm{CDCl}_{3}\right): \delta=8.30-8.26\left(\mathrm{~d}, 2 \mathrm{H},{ }^{3} J_{\mathrm{H}-\mathrm{H}}=9 \mathrm{~Hz}, \mathrm{H}_{2^{\prime}}\right.$ and $\left.\mathrm{H}_{6^{\prime}}\right), 7.82-7.77$ ( $\left.\mathrm{m}, 1 \mathrm{H}, \mathrm{H}_{7}\right), 7.61-7.57\left(\mathrm{~m}, 1 \mathrm{H}, \mathrm{H}_{4}\right), 7.41-7.35\left(\mathrm{~m}, 2 \mathrm{H}, \mathrm{H}_{5}\right.$ and $\left.\mathrm{H}_{6}\right)$, $7.26-7.21\left(\mathrm{~d}, 2 \mathrm{H},{ }^{3} \mathrm{~J}_{\mathrm{H}-\mathrm{H}}=9 \mathrm{~Hz}, \mathrm{H}_{3^{\prime}}\right.$ and $\left.\mathrm{H}_{5^{\prime}}\right) .{ }^{13} \mathrm{C}$ NMR $\left(\mathrm{CDCl}_{3}\right)$, $\delta \mathrm{ppm}=164.86\left(\mathrm{~d},{ }^{1} J_{\mathrm{C}-\mathrm{F}}=251.3 \mathrm{~Hz}, \mathrm{Cq}, \mathrm{C}_{4^{\prime}}\right), 162.19\left(\mathrm{Cq}, \mathrm{C}_{2}\right), 150.79$ (Cq, $\left.\mathrm{C}_{9}\right), 142.05\left(\mathrm{Cq}, \mathrm{C}_{8}\right), 129.87\left(\mathrm{~d},{ }^{3} \mathrm{~J}_{\mathrm{C}-\mathrm{F}}=9 \mathrm{~Hz}, \mathrm{CH}, \mathrm{C}_{2^{\prime}}\right.$ and $\mathrm{C}_{\mathrm{C}^{\prime}}$ ), $125.18\left(\mathrm{CH}, \mathrm{C}_{5}\right), 124.70\left(\mathrm{CH}, \mathrm{C}_{6}\right), 123.51\left(\mathrm{~d},{ }^{4} \mathrm{JC}_{\mathrm{F}} \mathrm{F}=3.75 \mathrm{~Hz}, \mathrm{Cq}, \mathrm{C}_{1^{\prime}}\right)$, $120.01\left(\mathrm{CH}, \mathrm{C}_{7}\right), 116.23\left(\mathrm{~d},{ }^{2} \mathrm{~J}_{\mathrm{C}-\mathrm{F}}=21.75 \mathrm{~Hz}, \mathrm{CH}, \mathrm{C}_{3^{\prime}}\right.$ and $\left.\mathrm{C}_{5^{\prime}}\right), 110.60$ $\left(\mathrm{CH}, \mathrm{C}_{4}\right)$. Anal. calcd. for $\mathrm{C}_{13} \mathrm{H}_{8} \mathrm{FNO}$ : $\mathrm{C}, 73.24 \% ; \mathrm{H}, 3.75 \%$;, $6.57 \%$. Found: C, 73.25\%; $\mathrm{H}, 3.30 \%$; $\mathrm{N}, 6.66 \%$. HRMS $\left(\mathrm{DCl}_{-} \mathrm{CH}_{4}\right), \mathrm{m} / \mathrm{z}$ $214.0673\left(\mathrm{M}+\mathrm{H}^{+}\right)$(calc. 214.0668). IR: $\nu_{\mathrm{C}=\mathrm{N}}: 1620 \mathrm{~cm}^{-1} ; \nu_{\mathrm{C}=\mathrm{C}}$ : $1577 \mathrm{~cm}^{-1} ; \nu_{\mathrm{N}}={ }_{\mathrm{C}-\mathrm{O}-}: 1560 \mathrm{~cm}^{-1}$.

\subsubsection{2-(4'-Chlorophenyl)-benzoxazole (2)}

Yield: $90 \%$. Mp: $150.2{ }^{\circ} \mathrm{C} .{ }^{1} \mathrm{H}$ NMR $\left(\mathrm{CDCl}_{3}\right), \delta \mathrm{ppm}=8.22(\mathrm{~d}, 2 \mathrm{H}$, $J=9 \mathrm{~Hz}, \mathrm{H}_{2^{\prime}}$ and $\left.\mathrm{H}_{6^{\prime}}\right) ; 7.84-7.78\left(\mathrm{~m}, 1 \mathrm{H}, \mathrm{H}_{7}\right) ; 7.64-7.58\left(\mathrm{~m}, 1 \mathrm{H}, \mathrm{H}_{4}\right)$; $7.53\left(\mathrm{~d}, 2 \mathrm{H}, J=9 \mathrm{~Hz}, \mathrm{H}_{3^{\prime}}\right.$ and $\left.\mathrm{H}_{5^{\prime}}\right) ; 7.43-7.37\left(\mathrm{~m}, 2 \mathrm{H}, \mathrm{H}_{5}\right.$ and $\left.\mathrm{H}_{6}\right) .{ }^{13} \mathrm{C}$ $\operatorname{NMR}\left(\mathrm{CDCl}_{3}\right), \delta \mathrm{ppm}=162.69\left(\mathrm{Cq}, \mathrm{C}_{2}\right), 150.76\left(\mathrm{Cq}, \mathrm{C}_{9}\right), 141.98(\mathrm{Cq}$, $\left.\mathrm{C}_{8}\right), 137.82\left(\mathrm{Cq}, \mathrm{C}_{1^{\prime}}\right), 129.32\left(\mathrm{CH}, \mathrm{C}_{3^{\prime}}\right.$ and $\left.\mathrm{C}_{5^{\prime}}\right), 128.88\left(\mathrm{CH}, \mathrm{C}_{2^{\prime}}\right.$ and $\left.\mathrm{C}_{6^{\prime}}\right)$, $125.65\left(\mathrm{Cq}, \mathrm{C}_{4^{\prime}}\right), 125.40\left(\mathrm{CH}, \mathrm{C}_{5}\right), 124.80\left(\mathrm{CH}, \mathrm{C}_{6}\right), 120.12\left(\mathrm{CH}, \mathrm{C}_{7}\right)$, $110.67\left(\mathrm{CH}, \mathrm{C}_{4}\right)$. Anal. calcd. for $\mathrm{C}_{13} \mathrm{H}_{8} \mathrm{ClNO}$ : C, 67.99\%; $\mathrm{H}, 3.51 \%$; N, 6.10\%. Found: C, 67.55\%; $\mathrm{H}, 3.15 \%$; N, 5.96\%. HRMS $\left(\mathrm{DCI}_{-} \mathrm{CH}_{4}\right), \mathrm{m} / \mathrm{z}$ $229.0294\left(\mathrm{M}+\mathrm{H}^{+}\right)$(calc. 229.0294). IR: $\nu_{\mathrm{C}=\mathrm{N}}: 1618 \mathrm{~cm}^{-1} ; \nu_{\mathrm{C}=\mathrm{C}}$ : $1579 \mathrm{~cm}^{-1} ; v_{-\mathrm{N}}={ }_{\mathrm{C}-\mathrm{O}-}: 1554 \mathrm{~cm}^{-1}$.

\subsubsection{2-(4'-Bromophenyl)-benzoxazole (3)}

Yield: $82 \%$ Mp: $159.8{ }^{\circ} \mathrm{C} .{ }^{1} \mathrm{H}$ NMR $\left(\mathrm{CDCl}_{3}\right), \delta \mathrm{ppm}=8.16(\mathrm{~d}, 2 \mathrm{H}$, $J=9 \mathrm{~Hz}, \mathrm{H}_{2^{\prime}}$ and $\left.\mathrm{H}_{6^{\prime}}\right) ; 7.83-7.79\left(\mathrm{~m}, 1 \mathrm{H}, \mathrm{H}_{7}\right) ; 7.71\left(\mathrm{~d}, 2 \mathrm{H}, J=9 \mathrm{~Hz}, \mathrm{H}_{3^{\prime}}\right.$ and $\left.\mathrm{H}_{5^{\prime}}\right) ; 7.63-7.60\left(\mathrm{~m}, 1 \mathrm{H}, \mathrm{H}_{4}\right) ; 7.42-7.39\left(\mathrm{~m}, 2 \mathrm{H}, \mathrm{H}_{5}\right.$ and $\left.\mathrm{H}_{6}\right) .{ }^{13} \mathrm{C}$ $\operatorname{NMR}\left(\mathrm{CDCl}_{3}\right), \delta \mathrm{ppm}=162.17\left(\mathrm{Cq}, \mathrm{C}_{2}\right), 150.77\left(\mathrm{Cq}, \mathrm{C}_{9}\right), 141.96(\mathrm{Cq}$, $\left.\mathrm{C}_{8}\right), 132.28\left(\mathrm{CH}, \mathrm{C}_{3^{\prime}}\right.$ and $\left.\mathrm{C}_{5^{\prime}}\right), 129.05\left(\mathrm{CH}, \mathrm{C}_{2^{\prime}}\right.$ and $\left.\mathrm{C}_{6^{\prime}}\right), 126.30\left(\mathrm{Cq}, \mathrm{C}_{4^{\prime}}\right)$, $126.09\left(\mathrm{Cq}, \mathrm{C}_{1^{\prime}}\right), 125.45\left(\mathrm{CH}, \mathrm{C}_{5}\right), 124.82\left(\mathrm{CH}, \mathrm{C}_{6}\right), 120.13\left(\mathrm{CH}, \mathrm{C}_{7}\right)$, $110.13\left(\mathrm{CH}, \mathrm{C}_{4}\right)$. Anal. calcd. for $\mathrm{C}_{13} \mathrm{H}_{8} \mathrm{BrNO}$ : C, 56.93\%; $\mathrm{H}, 2.92 \%$; $\mathrm{N}$,

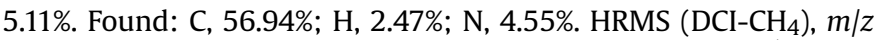
$273.9875\left(\mathrm{M}+\mathrm{H}^{+}\right)$(calc. 273.9868). IR: $\nu_{\mathrm{C}=\mathrm{N}}: 1615 \mathrm{~cm}^{-1} ; \nu_{\mathrm{C}=\mathrm{C}}$ : $1575 \mathrm{~cm}^{-1} ; v_{-\mathrm{N}}=\mathrm{C}-\mathrm{O}-: 1547 \mathrm{~cm}^{-1}$.

\subsubsection{2-(4'-Iodophenyl)-benzoxazole (4)}

Yield: $87 \%$. Mp: $180.2{ }^{\circ} \mathrm{C} .{ }^{1} \mathrm{H}$ NMR $\left(\mathrm{CDCl}_{3}\right), \delta \mathrm{ppm}=8.01(\mathrm{~d}, 2 \mathrm{H}$, $J=9 \mathrm{~Hz}, \mathrm{H}_{2^{\prime}}$ and $\left.\mathrm{H}_{6^{\prime}}\right) ; 7.91\left(\mathrm{~d}, 2 \mathrm{H}, J=9 \mathrm{~Hz}, \mathrm{H}_{3^{\prime}}\right.$ and $\left.\mathrm{H}_{5^{\prime}}\right) ; 7.84-7.78$ $\left(\mathrm{m}, 1 \mathrm{H}, \mathrm{H}_{7}\right) ; 7.64-7.58\left(\mathrm{~m}, 1 \mathrm{H}, \mathrm{H}_{4}\right) ; 7.43-7.37\left(\mathrm{~m}, 2 \mathrm{H}, \mathrm{H}_{5}\right.$ and $\left.\mathrm{H}_{6}\right) .{ }^{13} \mathrm{C}$ $\operatorname{NMR}\left(\mathrm{CDCl}_{3}\right), \delta \mathrm{ppm}=162.32\left(\mathrm{Cq}, \mathrm{C}_{2}\right), 150.75\left(\mathrm{Cq}, \mathrm{C}_{9}\right), 141.97(\mathrm{Cq}$, $\left.\mathrm{C}_{8}\right), 138.23\left(\mathrm{CH}, \mathrm{C}_{3^{\prime}}\right.$ and $\left.\mathrm{C}_{5^{\prime}}\right), 129.00\left(\mathrm{CH}, \mathrm{C}_{2^{\prime}}\right.$ and $\left.\mathrm{C}_{6^{\prime}}\right), 126.64\left(\mathrm{Cq}, \mathrm{C}_{1^{\prime}}\right)$, $125.48\left(\mathrm{CH}, \mathrm{C}_{5}\right), 124.82\left(\mathrm{CH}, \mathrm{C}_{6}\right), 120.15\left(\mathrm{CH}, \mathrm{C}_{7}\right), 110.70\left(\mathrm{CH}, \mathrm{C}_{4}\right)$, $98.53\left(\mathrm{Cq}, \mathrm{C}_{4^{\prime}}\right.$ ). Anal. calcd. for $\mathrm{C}_{13} \mathrm{H}_{8} \mathrm{INO}$ : C, $48.62 \%$; $\mathrm{H}, 2.51 \%$; $\mathrm{N}$, 4.36\%. Found: C, 48.45\%; H, 2.05\%; N, 4.20\%. HRMS (DCI-CH $)_{4}, \mathrm{~m} / \mathrm{z}$ $320.9648\left(\mathrm{M}+\mathrm{H}^{+}\right)$(calc. 320.9651). IR: $\nu_{\mathrm{C}=\mathrm{N}}: 1613 \mathrm{~cm}^{-1} ; \nu_{\mathrm{C}=\mathrm{C}}$ : $1586 \mathrm{~cm}^{-1} ; v_{-\mathrm{N}}={ }_{\mathrm{C}-\mathrm{O}-}: 1569 \mathrm{~cm}^{-1}$.

\subsection{Crystallographic data}

Data were collected at a temperature of 193(2) K on a Bruker-AXS APEX II diffractometer using a $30 \mathrm{~W}$ air-cooled microfocus source (ImS) with focusing multilayer optics for $\mathbf{1}, \mathbf{2}$ and $\mathbf{5}$ and on a BrukerAXS SMART APEX II diffractometer for $\mathbf{3}$ and $\mathbf{4}$ with graphitemonochromated MoK $\alpha$ radiation (wavelength $=0.71073 \AA$ ) by using phi- and omega-scans. The structures were solved by direct methods and all non-hydrogen atoms were refined anisotropically using the least-square method on $F^{2}$ [26].

CCDC 856670 (1), CCDC 1008778 (2), CCDC 856671 (3), CCDC 1008779 (4) and CCDC 875804 (5) contain the supplementary 
crystallographic data for the structures. These data can be obtained free of charge via www.ccdc.cam.ac.uk/data_request/cif (or for the CCDC, 12 Union Road, Cambridge CB2 1EZ, UK; fax: +44 1223 336033; e-mail: deposit@ccdc.cam.ac.uk).

\subsection{Apparatus and methods}

The melting points were measured on a Stuart Automatic SMP40 apparatus. High resolution mass spectra were obtained at the "Service Commun de Spectrométrie de masse de l'Université Paul Sabatier de Toulouse" with a Waters GCT Premier spectrometer using the chemical ionization technique with $\mathrm{CH}_{4}$. The microanalyses were obtained with a Perkin Elmer 2400 series II elemental analyzer in the "Service d'Analyse Chimique du Laboratoire de Chimie de Coordination de Toulouse". The IR spectra were measured on a Nexus Thermonicolet at the "Service Commun de Spectroscopie Infra-Rouge et Raman de l'Université Paul Sabatier de Toulouse". The NMR spectra were recorded on a Bruker AC 300 spectrometer operating at $300.13 \mathrm{MHz}$ for ${ }^{1} \mathrm{H}$ and $75.49 \mathrm{MHz}$ for ${ }^{13} \mathrm{C}$. Attributions were owing to $2 \mathrm{D}$ NMR data. The microanalyses were obtained with a Perkin Elmer 2400 Series II elemental analyzer in the "Service de micro-analyses du LCC de Toulouse".

For solutions, spectroscopic measurements were conducted at $20{ }^{\circ} \mathrm{C}$ in a temperature-controlled cell. The step between two measurements was $2 \mathrm{~nm}$. UV $\rightarrow$ Vis absorption spectra were recorded on a Hewlett $\rightarrow$ Packard 8452A diode array spectrophotometer.

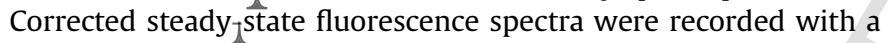
Photon Technology International (PTI) Quanta Master 1 spectrofluorometer. The fluorescence quantum yields $\left(\Phi_{\mathrm{F}}\right)$ in solutions were determined using the classical formula: $\Phi_{\mathrm{Fx}}=\left(A_{S} \times F_{x} \times n_{x}^{2} \times \Phi_{\mathrm{Fs}}\right) /\left(A_{x} \times F_{S} \times n_{s}^{2}\right)$ where $A$ is the absorbance at the excitation wavelength, $F$ the area under the fluorescence curve and $n$ the refraction index of the solvent used. Subscripts $s$ and $x$ refer to the standard and to the sample of unknown quantum yield, respectively. 2 -Phenyl-benzoxazole in cyclohexane $\left(\Phi_{\mathrm{F}}=0.78\right)$ was taken as the standard [27]. The fluorescence quantum yields were measured by exciting the samples at their absorption maximum. The absorbance of the solutions was equal or below 0.05 at the excitation wavelength. The error on the quantum yield values was estimated to be between 5 and 10\%.

For solid ${ }_{7}$ state measurements, the diffuse reflectance spectra of the powders were measured with a Perkin Elmer 860 Spectrophotometer equipped with a $15 \mathrm{~cm}$ diameter integrating sphere bearing the holder in the bottom horizontal position. They were recorded at room temperature in steps of $1 \mathrm{~nm}$, in the range $250-400 \mathrm{~nm}$ with a bandwidth of $2 \mathrm{~nm}$. The instrument was calibrated with a certified Spectralon white standard (Labsphere, North Sutton, USA) and spectra were acquired by inserting before the detector a visible short-wave pass filter (LOT-Oriel 400FL07-50, 400 cut-off wavelength) in order to remove the fluorescence component of the benzoxazole derivative. The Kubelka-Munk model described light penetration in homogenous and optically thick media with only two parameters: an absorption coefficient, $K$, and anisotropic scattering coefficient, $\mathrm{S}$ (both in $\mathrm{cm}^{-1}$ ) [28]. This model allowed us to deduce that there was a simple relationship between the reflectance at "infinite thickness" and the absorption and scattering coefficients: $F\left(R_{\infty}\right)=\left(1-R_{\infty}\right) 2 / 2 R_{\infty}=K / S$. For materials where the dye did not aggregate and did not fluoresce, the law could be applied, so that $K$ was the dye absorptivity ( $\varepsilon$ in $\mathrm{M}^{-1} \mathrm{~cm}^{-1}$ ) scaled by the effective concentration $C(\mathrm{M})$. The $K / S$ ratio was then equal to $K / S=(\varepsilon \times C) / S$. Photoluminescence quantum yields were recorded on a Xenius SAFAS spectrofluorometer equipped with a $\mathrm{BaSO}_{4}$ integrating sphere and a Hamamatsu R2658 detector. Solid samples were deposited on a metal support and luminescence spectra were corrected. The excitation source was scanned in order to evaluate the reflected light for the empty sphere $\left(L_{a}\right)$, the samples facing the source light $\left(L_{c}\right)$ and the sample out of the irradiation beam $\left(L_{b}\right)$. The fluorescence spectra were recorded with the sample facing the source light $\left(E_{c}\right)$ and out from the direct irradiation $\left(E_{b}\right)$. The PM voltage was adapted to the measurement of reflected light and emission spectra, respectively, and proper correction was applied to take into account the voltage difference. The absolute photoluminescence quantum yield values $\left(\Phi_{\mathrm{P}}\right)$ were determined using the formula [29]:

$$
\Phi_{P}=\frac{E_{c}-(1-\alpha) \cdot E_{b}}{L_{a} \cdot \alpha}
$$

with

$\alpha=1-\frac{L_{c}}{L_{b}}$

The error on the photoluminescence quantum yield values was estimated to be around $20 \%$.

\section{Results and discussion}

\subsection{Spectroscopic properties in solution}

The halogenated 2-phenyl-benzoxazole derivatives $1-4$ were synthesized according to a classical procedure, by condensing 2aminophenol with the appropriate acyl chloride, in stoichiometric proportions. Before studying the solid-state properties of these compounds, their $\mathrm{UV}_{7}$ vis absorption and fluorescence properties were examined in $n$-heptane and ethanol solutions. The data were collected in Table 1. They were useful to expand the data set that had been previously reported about the compounds dissolved in

Table 1

Spectroscopic properties of 2-phenyl-benzoxazole derivatives 1-5 dissolved in organic solvents and as microcrystalline powders. Maximum absorption ( $\lambda_{\text {abs }}$ ) and emission wavelength $\left(\lambda_{\text {em }}\right)$, diffuse reflectance $\left(\lambda_{\text {ref }}\right)$, fluorescence and photoluminescence quantum yields ( $\Phi_{\mathrm{F}}$ and $\Phi_{\mathrm{P}}$, respectively).

\begin{tabular}{|c|c|c|c|c|c|c|c|c|c|}
\hline & \multicolumn{3}{|c|}{ Solution in $n$-heptane } & \multicolumn{3}{|c|}{ Solution in ethanol } & \multicolumn{3}{|l|}{ Solid state } \\
\hline & $\lambda_{\text {abs }}(\mathrm{nm})$ & $\lambda_{\mathrm{em}}{ }^{\mathrm{a}}(\mathrm{nm})$ & $\Phi_{\mathrm{F}}^{\mathrm{a}}$ & $\lambda_{\mathrm{abs}}(\mathrm{nm})$ & $\lambda_{\mathrm{em}}{ }^{\mathrm{a}}(\mathrm{nm})$ & $\Phi_{\mathrm{F}}{ }^{\mathrm{a}}$ & $\lambda_{\text {ref }}(\mathrm{nm})$ & $\lambda_{\mathrm{em}}^{\mathrm{b}}(\mathrm{nm})$ & $\Phi_{\mathrm{P}}{ }^{\mathrm{b}}$ \\
\hline $\mathrm{Bzx}-\mathrm{F}(\mathbf{1})$ & $290, \underline{298}, 312$ & $312, \underline{328}, 344$ & 0.73 & $290, \underline{298}, 312 \mathrm{~s}$ & $322, \underline{336}, 350$ & 0.80 & 333 & 366 & 0.15 \\
\hline $\mathrm{Bzx}-\mathrm{Cl}(\mathbf{2})$ & $296, \overline{304}, 318$ & $322, \overline{338}, 354$ & 0.55 & $296, \overline{304}, 318 \mathrm{~s}$ & $328, \overline{344}, 358$ & 0.67 & 348 & 394 & 0.28 \\
\hline $\operatorname{Bzx}-\operatorname{Br}(3)$ & $294, \overline{306}, 320$ & $320, \overline{336}, 352$ & 0.18 & $294, \overline{306}, 318 \mathrm{~s}$ & $328, \overline{344}, 358$ & 0.23 & 342 & 386 & 0.05 \\
\hline Bzx-I (4) & $300, \overline{308}, 324$ & $322 \mathrm{~s}, \overline{336}, 346$ & 0.01 & $302, \overline{308}, 324 \mathrm{~s}$ & $336, \overline{348}, 352$ & 0.03 & 333 & nd & nd \\
\hline $\mathrm{Bzx}-\mathrm{H}(5)^{\mathrm{c}}$ & $292,298,312$ & $316,330,346$ & 0.69 & $292,298,312 \mathrm{~s}$ & $322,336,350$ & 0.73 & 345 & 360 & 0.26 \\
\hline
\end{tabular}

$\mathrm{s}=$ shoulder; $\mathrm{nd}=$ not detected.

a $\lambda_{\mathrm{ex}}=300 \mathrm{~nm}$.

b $\lambda_{\mathrm{ex}}=310 \mathrm{~nm}$

${ }^{c}$ Data from Ref. [9]. Maxima underlined. Dye concentration: $1.1 \times 10^{-5} \mathrm{M}$ for absorption measurements and $1.1 \times 10^{-6} \mathrm{M}$ for fluorescence. 
cyclohexane [11]. In absorption, the dissolved compounds exhibited a broad UV band with fine vibrational structure, attributable to a $\mathrm{S}_{0} \rightarrow \mathrm{S}_{1}\left(\pi \pi^{*}\right)$ transition [27,30-33]. The spectra were very similar in both solvents, showing that the absorption properties were relatively insensitive to the solvent polarity and proticity. A progressive red shift of the absorption spectrum was noticed with increasing the size of the halogen atom. For instance, the absorption maximum was $298 \mathrm{~nm}$ for the fluorinated derivative $\mathbf{1}$ and $308 \mathrm{~nm}$ for the iodinated derivative 4 .

The fluorescence excitation spectra were identical to the absorption spectra. An example was given for compound $\mathbf{1}$ in Fig. 2. The fluorescence emission spectra appeared like a broad, wellresolved band that was situated between 300 and $430 \mathrm{~nm}$ and mirrored the absorption band. The spectra in ethanol were shifted to the red with respect to $n$-heptane (Fig. 2). This weak solvatochromic effect indicated that the excited state was slightly more polar than the ground state.

The fluorinated compound $\mathbf{1}$ was a very good emitter in the near-UV region. For example, the fluorescence quantum yield $\left(\Phi_{\mathrm{F}}\right)$ measured in $n$-heptane was as high as 0.73 . In solution, this compound was therefore very similar to the unsubstituted derivative $\mathbf{5}$. For the other members of the series, the presence of the halogen atom became apparent. The $\Phi_{\mathrm{F}}$ values were decreased with increasing the halogen size. Small differences were found for the same compound depending on the solvent, but the same general trend was observed in $n$-heptane and ethanol. The quantum yields were first weakly decreased from $\mathbf{1}$ to $\mathbf{2}$, and then an abrupt collapse occurred from the brominated derivative $\mathbf{3}$. The iodinated compound 4 was very weakly emissive, the $\Phi_{\mathrm{F}}$ value in $n$-heptane being only 0.01 . These results were close to those reported in cyclohexane solutions [11]. This monotonous evolution was attributed to heavy atom effect.

\subsection{Spectroscopic properties in the solid state}

Compounds were then studied as microcrystalline powders. The reflectance spectra of the compounds were markedly shifted to long wavelengths with respect to solutions (Fig. 3(a)), illustrating the presence of specific interactions between the molecules in the solid state. However similar trends between solids and solutions were observed. The wavelength corresponding to the maximum of absorption showed small variations with the substituent. Compound 1 bearing fluorine always presented the lowest value while compound 2 bearing chlorine had the highest one (Table 1 ).

The solid-state emission properties were investigated using a spectrofluorometer equipped with an integrating sphere.

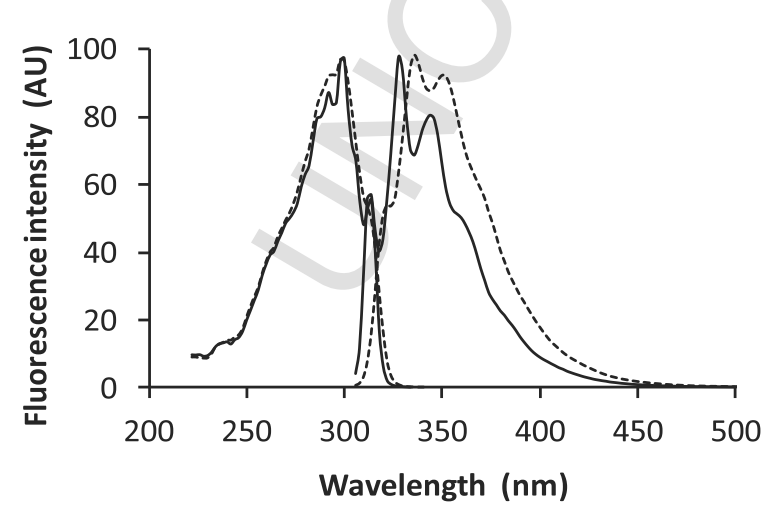

Fig. 2. Normalized excitation and emission spectra of the fluorinated derivative $\mathbf{1}$ at $1.1 \times 10^{-6} \mathrm{M}$ in $n$-heptane (solid lines) and ethanol (dotted lines). For excitation spectra, $\lambda_{\mathrm{em}}=344 \mathrm{~nm}$ in $n$-heptane and $351 \mathrm{~nm}$ in ethanol. For emission spectra, $\lambda_{\mathrm{ex}}=300 \mathrm{~nm}$ in both solvents.

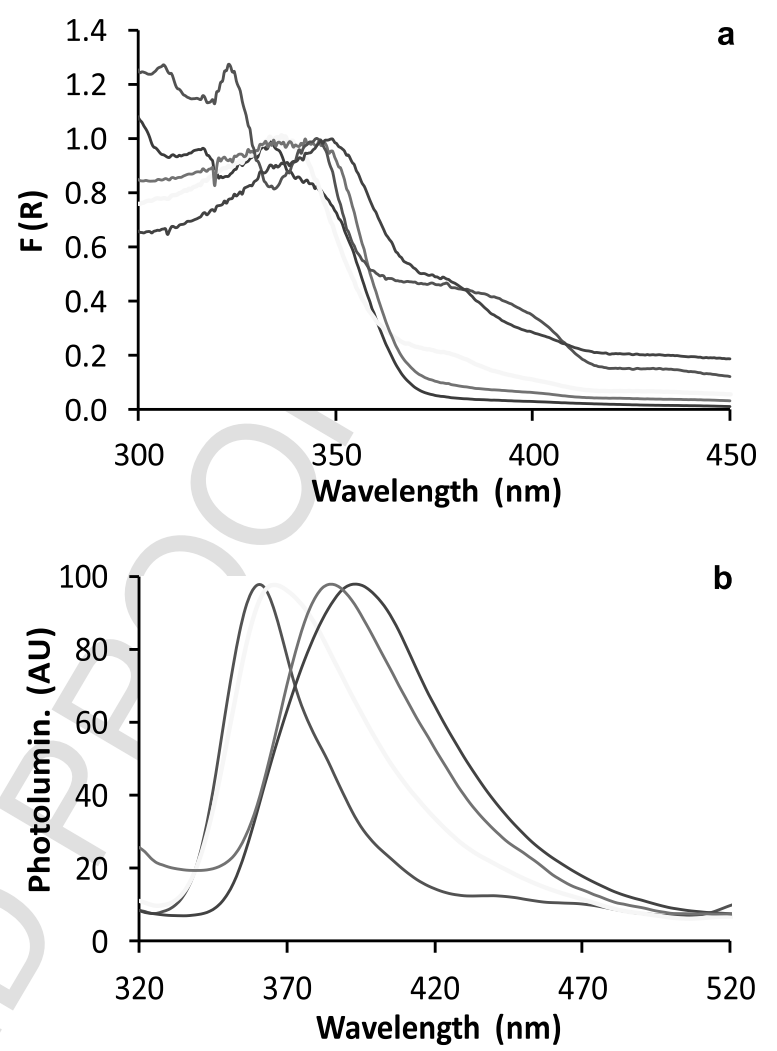

66

67

68

Fig. 3. (a) Remission function of the UV-visible diffuse reflectance spectra of powder compounds $\mathbf{1}$ (yellow line), $\mathbf{2}$ (green line), $\mathbf{3}$ (orange line), $\mathbf{4}$ (purple line) and $\mathbf{5}$ (blue line), normalized on the absorption maximum. (b) Normalized photoluminescence spectra $\left(\lambda_{\mathrm{ex}}=310 \mathrm{~nm}\right.$ ) of powder compounds $\mathbf{1 , 2 , 3}$ and $\mathbf{5}$ (same,color code as above). Emission from compound $\mathbf{4}$ could not be detected. (For interpretation of the references to colour in this figure legend, the reader is referred to the web version of this article.)

Microcrystalline compounds 1, $\mathbf{2}$ and $\mathbf{3}$ emitted in the blue when excited with UV light. Their photoluminescence spectra were redshifted by $30 \mathrm{~nm}$ or more with respect to the fluorescence spectra recorded in solution (Table 1). Vibrational resolution was not distinguished. An explanation could be that distinct populations of fluorophores, each of them with a different environment, co-exist in the solid state, and emission would be the sum of all contributions. The photoluminescence spectrum of the unsubstituted compound $\mathbf{5}$ was much narrower than that of the halogenated compounds. At longer wavelengths appeared the spectrum of the fluorinated derivative $\mathbf{1}$, and then the spectra of the brominated (3) and chlorinated (2) derivatives, respectively (Fig. 3(b)). The iodinated derivative $\mathbf{4}$ was virtually not emissive, no spectrum could be registered using our apparatus.

The photoluminescence quantum yields $\Phi_{\mathrm{P}}$ (Table 1 ) were lower than the corresponding values measured in solution, but of the same order of magnitude. It was noteworthy that the maximum $\Phi_{\mathrm{P}}$ value was now obtained for the chlorinated derivative $\mathbf{2}$.

Plotting on the same graph the fluorescence and photoluminescence quantum yields versus the halogen atomic radius [34] seemed relevant to us to compare the evolution of these processes (Fig. 4). Both types of curves showed a similar fall with passing from the chlorinated (2) to the iodinated (4) derivative. However, their shape was different because the photoluminescence quantum yield values of compounds $\mathbf{1}$ and $\mathbf{2}$ were not aligned as the fluorescence ones. Either the fluorinated derivative $\mathbf{1}$ had a lower quantum yield, or the chlorinated derivative $\mathbf{2}$ had a higher quantum yield than the expected value. The first proposition seemed to be the most likely. Indeed, the fluorinated compound $\mathbf{1}$ also had 


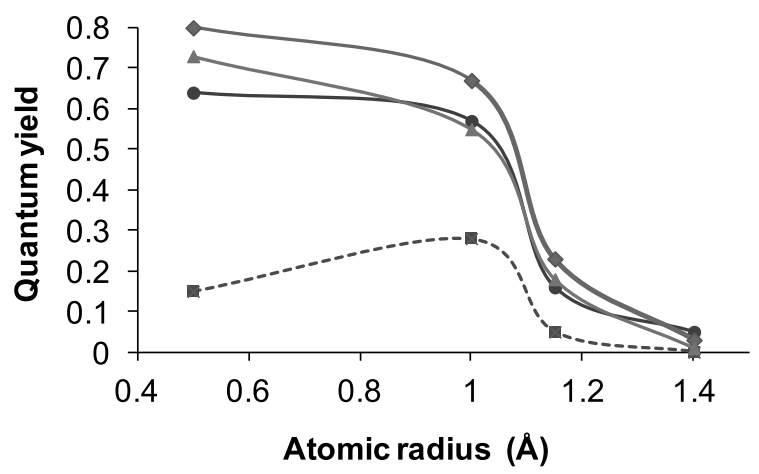

Fig. 4. Evolution of the fluorescence quantum yields of compounds $1-4$ in $n$-heptane (green line), ethanol (blue line) and cyclohexane (purple line) (data from Ref. [11]) and photoluminescence quantum yields of the same compounds as powders (red line), versus the mean radius of the halogen atom [34]. (For interpretation of the references to colour in this figure legend, the reader is referred to the web version of this article.)

lower photoluminescence efficiency than the unsubstituted analog $\mathbf{5}$, in contrast with what occurred in solution. So, its emission efficiency in the solid state was thought to be lower than what it should be.

Obviously, the heavy atom effect also took place in the solid state. However, it did not allow the behavior of the fluorinated compound to be explained. Other influences were thus considered. It is now well acknowledged that solid-state emission properties strongly depend on many factors, among which the presence of impurities, crystal defects and molecular arrangement. Despite the fact that special care was brought here to the preparation of the compounds, which all were extensively purified according to a similar protocol, the effect of impurity or crystal defects in $\mathbf{1}$ could not be totally ruled out. However, it was most likely that the observed discrepancy came from different molecular arrangements in the solid state. This is the reason why the crystal packing mode was investigated.

\subsection{Crystal packing mode}

Crystals were grown in THF by slow evaporation of the solvent and X-ray analyses were performed. The data were gathered in Table 2. Compound $\mathbf{1}$ crystallized in triclinic space group $P \overline{1}$, while the other three halogenated analogs crystallized in monoclinic space groups ( $P 2_{1} / \mathrm{n}$ for $\mathbf{2}$ and $\mathbf{3}$, and $P 2_{1}$ for $\left.\mathbf{4}\right)$. The molecules were planar for all compounds. For 1-3, the crystal unit contained four molecules that were arranged by pairs. Molecules $\mathrm{AA}^{\prime}$ and $\mathrm{BB}^{\prime}$ were situated on two distinct planes that formed between them an angle of about $21.9^{\circ}, 39.7^{\circ}$ and $37.1^{\circ}$ for $\mathbf{1}, 2$ and 3, respectively (Fig. 5(a)-(c)). For 4, the crystal unit only contained two molecules that formed between them an angle of $86.7^{\circ}$ (Fig. 5(d)). Let us now consider the arrangement of the molecules with respect to their nearest neighbors situated above and below them in parallel planes. For every compound, the interplanar distance was around 3.5 $\AA$, which allowed strong $\pi-\pi$ interactions. Molecules of $\mathbf{1}$ were stacked anti-parallel (Fig. 5(e)). In contrast, molecules of 2 (Fig. 5(f)), $\mathbf{3}$ and $\mathbf{4}$ were arranged as slipped parallel. The shift between the nearest stacked molecules was increased with increasing the halogen size (Table 2).

It is noteworthy that for compounds $\mathbf{1}, \mathbf{2}$ and $\mathbf{3}$, short contacts were established between molecules situated in the same plane. They involved at least one of the two heteroatoms of the oxazole ring, as well as the fluorine atom, but not the chlorine and bromine atoms. For compound 4, short contacts were established between molecules arranged perpendicularly, involving the oxygen and nitrogen atoms, as well as the iodine atom (Fig. 5(d)). Most curiously, the resolution of structures of compounds $\mathbf{2}$ and $\mathbf{3}$ showed that molecules may take two different positions in the crystal unit, with an inversion of the $\mathrm{O}$ and $\mathrm{N}$ atoms.

Table 2

Crystal data of compounds $1-5$

\begin{tabular}{|c|c|c|c|c|c|}
\hline & Bzx-H (5) & $\mathrm{Bzx}-\mathrm{F}(\mathbf{1})$ & $\mathrm{Bzx}-\mathrm{Cl}(\mathbf{2})$ & $\operatorname{Bzx}-\mathrm{Br}(\mathbf{3})$ & Bzx-I (4) \\
\hline \multirow[t]{2}{*}{ Molecule } & $\mathrm{C}_{13} \mathrm{H}_{9} \mathrm{NO}$ & $\mathrm{C}_{13} \mathrm{H}_{8} \mathrm{FNO}$ & $\mathrm{C}_{13} \mathrm{H}_{8} \mathrm{ClNO}$ & $\mathrm{C}_{13} \mathrm{H}_{8} \mathrm{BrNO}$ & $\mathrm{C}_{13} \mathrm{H}_{8} \mathrm{INO}$ \\
\hline & $\mathrm{M}=195.21$ & $\mathrm{M}=213.20$ & $M=229.65$ & $\mathrm{M}=274.11$ & $\mathrm{M}=321.10$ \\
\hline \multirow{6}{*}{$\begin{array}{l}\text { Crystal system } \\
\text { Space group } \\
\text { Cell coordinates }\end{array}$} & Orthorhombic & Triclinic & Monoclinic & Monoclinic & Monoclinic \\
\hline & Cmca & $P \overline{1}$ & $P 2_{1} / n$ & $P 2_{1} / n$ & $P 2_{1}$ \\
\hline & $a=11.1566(13) \AA$ & $a=6.5750(9) \AA$ & $a=11.9168(9) \AA$ & $a=11.9844(6) \AA$ & $a=10.5593(5) \AA$ \\
\hline & $b=6.0329(5) \AA$ & $b=7.3542(11) \AA$ & $b=3.8262(2) \AA$ & $b=3.8929(3) \AA$ & $b=5.1134(3) \AA$ \\
\hline & $c=14.5965(13) \AA$ & $c=22.694(4) \AA$ & $c=22.6325(17) \AA$ & $c=22.6646(12) \AA$ & $c=11.1590(5) \AA$ \\
\hline & & $\begin{array}{l}\alpha=92.980(10)^{\circ} \\
\beta=90.929(9)^{\circ} \\
\gamma=116.002(6)^{\circ}\end{array}$ & $\beta=92.759(3)^{\circ}$ & $\beta=92.397(4)^{\circ}$ & $\beta=110.045(3)^{\circ}$ \\
\hline Volume & $982.44(17) \AA^{3}$ & $984.0(3) \AA^{3}$ & $1030.76(12) \AA^{3}$ & $1056.47(11) \AA^{3}$ & $566.02(5) \AA^{3}$ \\
\hline \multirow{4}{*}{$\begin{array}{l}Z \\
\text { Reflections collected }\end{array}$} & 8 & 4 & 4 & 4 & 2 \\
\hline & 18,533 & 16,940 & 12,528 & 5464 & 7176 \\
\hline & (925 independent & (3310 independent & (2426 independent & (2113 independent & (2528 independent \\
\hline & $\left.R_{\text {int }}=0.0309\right)$ & $\left.R_{\mathrm{int}}=0.0479\right)$ & $\left.R_{\mathrm{int}}=0.0513\right)$ & $\left.R_{\mathrm{int}}=0.0403\right)$ & $\left.R_{\text {int }}=0.0657\right)$ \\
\hline \multirow[t]{2}{*}{ Parameters } & 124 parameters & 289 parameters & 163 parameters & 165 parameters & 145 parameters \\
\hline & 142 restraints & & 4 restraints & 46 restraints & 1 restraints \\
\hline$R_{1}[I>2 \sigma(I)]$ & 0.0369 & 0.1023 & 0.0360 & 0.0384 & 0.0587 \\
\hline$w R 2$ [all data] & 0.0962 & 0.2609 & 0.1030 & 0.0903 & 0.1485 \\
\hline Largest diff. peak and hole & 0.177 and -0.248 e. $\AA^{-3}$ & 0.469 and -0.347 e..$\AA^{-3}$ & 0.245 and -0.286 e. $\AA^{-3}$ & 0.502 and -0.430 e. $\AA^{-3}$ & 2.194 and -1.571 e. $\AA^{-3}$ \\
\hline $\begin{array}{l}\text { Angle between the planes } \\
\text { of } A \text { and } B\end{array}$ & $72^{\circ}$ & $21.9^{\circ}$ & $39.7^{\circ}$ & $37.1^{\circ}$ & $86.7^{\circ}$ \\
\hline \multirow{2}{*}{$\begin{array}{l}\text { Number and length of short } \\
\text { contacts for mol. A and B }\end{array}$} & - & A: $5(2.3-2.7 \AA)$ & A: $3(2.3-2.7 \AA)$ & A: $5(2.2-2.9 \AA)$ & A: $10(2.6-3.9 \AA)$ \\
\hline & & B: $3(2.5-2.7 \AA)$ & B: $3(2.3-2.7 \AA)$ & B: $5(2.2-2.9 \AA)$ & B: $10(2.6-3.9 \AA)$ \\
\hline Stacking arrangement & Parallel & Anti-parallel & Parallel & Parallel & Parallel \\
\hline $\begin{array}{l}\text { Shift between nearest } \\
\text { stacked molecules }\end{array}$ & $5.04 \AA$ & $0.6 \AA$ & $0.95 \AA$ & $1.2 \AA$ & $3.12 \AA$ \\
\hline $\mathrm{O}$ and $\mathrm{N}$ inversion & Yes & No & Yes & Yes & No \\
\hline
\end{tabular}




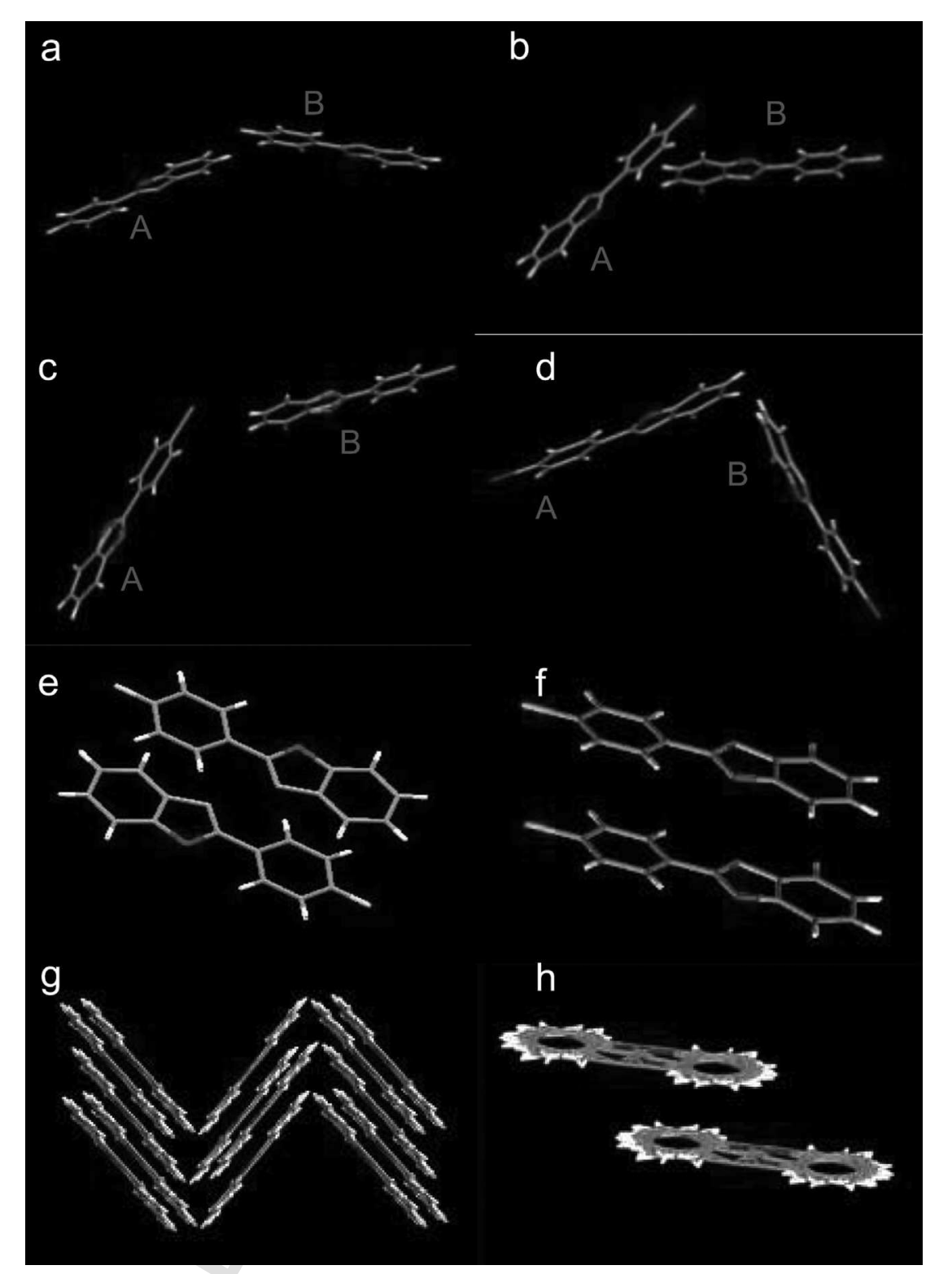

Fig. 5. Arrangement of molecules $A$ and $B$ (molecules $A^{\prime}$ and $B^{\prime}$ not represented) in the crystal cell of 4-halogenated 2-phenyl-benzoxazoles: (a) fluorine, (b) chlorine and (c) bromine derivatives 1, 2 and 3, respectively. (d) Crystal cell of the iodine derivative $\mathbf{4}$. Stacking of (e) $\mathbf{1}$ and (f) 2. (g and h) Molecular arrangement of unsubstituted compound $\mathbf{5}$.

It was interesting to compare the molecular arrangement of the halogenated compounds with that of unsubstituted 2-phenylbenzoxazole (5). The space group and unit cell dimensions of this compound had been reported by Rao and Murthy in 1966 [35], but no data were available concerning the relative orientation of the molecules. This is the reason why an X-ray analysis was performed in the present work. The result was quite surprising. All molecules behaved as if they were totally symmetric. No distinction was made between the $\mathrm{O}$ and $\mathrm{N}$ atoms of the oxazole ring, and the phenyl group in the 2-position could not be distinguished from the fused phenyl ring of the benzoxazole group. It was therefore totally impossible to determine the orientation of the molecules with respect to each other. In contrast, it was clear that molecules were distributed in the crystal unit according to two different planes, forming between them an angle of around $72^{\circ}$ (Fig. 5(g)). The molecules displayed a herringbone arrangement. Those situated in adjacent parallel planes were stacked but strongly shifted one with respect to other, and separated by about $3.6 \AA$ (Fig. 5(h)). It can be noted that the crystal packing mode (orthorhombic) was the same than that reported in the literature [35], the cell dimensions were very close, but the space group was different. This discrepancy may be attributed to the evolution of apparatus and techniques that makes structure resolution more precise nowadays.

To make a link between the crystal packing mode and the photoluminescence properties, it is necessary to consider the transition dipole moments, which are expected to be orientated along the long axis of the 2-phenyl-benzoxazole molecules [36], and the overlap of the electron conjugated systems. In the crystal of unsubstituted 2-phenyl-benzoxazole (5), molecules were strongly shifted, so that the overlap of the aromatic systems was reduced. This arrangement can favor photoluminescence [37]. Moreover, the relative orientation of the stacked molecules was not discernible. This particular distribution could generate a broad emission spectrum, which was not observed. The halogenated compounds showed other types of molecular arrangement. For 1, molecules were stacked anti-parallel, meaning that the transition dipole 
moments are in opposite direction. The very strong overlap of the aromatic rings could disfavor light emission, and explain that the photoluminescence quantum yield was lower than expected in view of the behavior in solution. For 2, 3 and 4, molecules were stacked parallel, but slipped with respect to each other, and so the aromatic rings did not totally overlap. For $\mathbf{2}$ and 3, the nitrogen/ oxygen inversion also introduced some disorder in the crystal structure. It is possible that this arrangement is beneficial to light emission. The most favorable configuration was paradoxically encountered for the iodinated derivative 4. Molecules situated in the same plane were strongly shifted and molecules situated in different planes were displayed perpendicularly, which results in stabilization of the dipole transition moment [37,38]. This molecular arrangement was strongly reminiscent of that found for 2tolyl-benzoxazole [9], which was very emissive in the solid state. Unfortunately, for compound 4, the heavy atom effect makes the molecules virtually not fluorescent.

\subsection{Formation of microparticles}

The aim of our work on benzoxazole derivatives was to prepare fluorescent nanoparticles. Consequently, it seemed interesting to study the type of particles that were formed spontaneously using a simple preparation method, knowing that the nature of the substituent generally influences their size and shape on a still unpredictable way. The reprecipitation method is a mild method, based on solvent exchange. Primarily developed by Nakanishi and coworkers $[39,40]$, it has proved to be very useful to us in preparing nano- and micro-crystals of various organic dyes [41-43], including benzoxazole and naphthoxazole dyes [9,10]. It generally consists in dissolving the organic compounds in a hydrophilic solvent, and then pouring a small volume of this concentrated solution into a large volume of water. This abrupt solvent exchange prompts the aggregation of the organic compounds, and then the formation of nano- or micro-particles in aqueous suspension. In the present case, reprecipitation was performed as described in the experimental section, leading to a dye suspension at $2 \times 10^{-4} \mathrm{M}$ in water/ ethanol $(98: 2 \mathrm{v} / \mathrm{v})$. After filtration and drying under vacuum for 2 days at $45{ }^{\circ} \mathrm{C}$, the deposit was analyzed by scanning electron microscopy (Fig. 6).

For the compounds 1, 2 and 3, micrometer-size particles were observed. For the fluorinated derivative 1, at first sight, the sample showed two types of objects. Most of the particles looked like a tangle of dried tea leaves; others, though few, looked like balls. Both seemed to result from the superposition of very thin sheets. The chlorinated derivative $\mathbf{2}$ gave the same type of objects, but in this case spherical microstructures measuring between 1 and $3 \mu \mathrm{m}$ were predominant. They were made by layers of elongated sheets and showed a tendency to agglomeration. It can be thought that these spherical structures are artifacts caused by drying, because observation of the suspensions of $\mathbf{2}$ by fluorescence microscopy only revealed the presence of elongated thin microcrystals. The brominated derivative 3 led to long and flat microcrystals measuring about $10 \mu \mathrm{m} \times 1 \mu \mathrm{m}$, with a thickness around $300 \mathrm{~nm}$. Finally, the iodinated derivative 4 gave cubic sub-micrometric crystals measuring in average $0.4 \mu \mathrm{m} \times 0.5 \mu \mathrm{m}$.

The spontaneous formation of microparticles is therefore favored by the presence of the halogen atom, which enhances the hydrophobicity by comparison with unsubstituted derivative $\mathbf{5}$. It can be recalled that $\mathbf{5}$ led to shapeless nano- and micro-crystals of very heterogeneous size. In the present case, the halogenated derivatives led to regular microcrystals, the shape of which closely depends on the nature of the halogen atom. Obtaining homogeneous microcrystals by the simple reprecipitation method could be a distinct advantage for the preparation of materials. According to our experience in this field, the particle size can be reduced by changing the experimental parameters, but most often, nanocrystals retain the same shape than microcrystals.
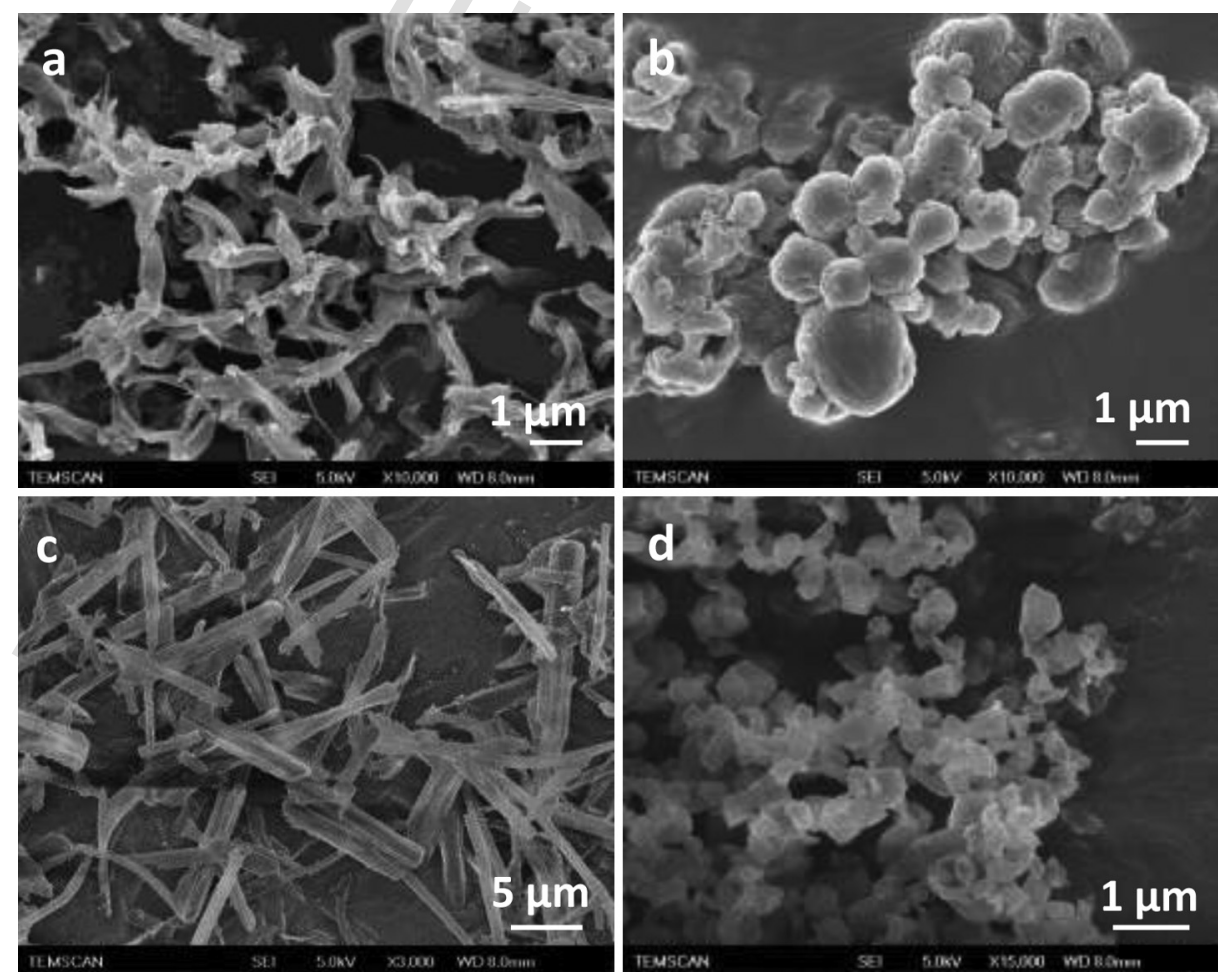

Fig. 6. Scanning electron microscopy images of the microparticles obtained by reprecipitation of the halogenated 2-phenyl-benzoxazole derivatives $\mathbf{1}$ (a), 2 (b), 3 (c) and $\mathbf{4}$ (d) in water with $2 \% \mathrm{v} / \mathrm{v}$ ethanol (compounds at $2 \times 10^{-4} \mathrm{M}$ in aqueous suspensions). 


\section{Conclusion}

The study of halogenated 2-phenyl-benzoxazoles confirmed that predicting the solid-state properties of fluorophores is particularly challenging. The optical characteristics of dyes in solution are not directly transposable to the solid state, because the solid-state properties are influenced by many factors. In the present case, the intrinsic properties of the dyes, governed by heavy atom effect, were modulated by the influence of the molecular arrangement. The type of microparticles spontaneously obtained using a solvent-exchange method is also hardly predictable. This shows the necessity to extend this type of study to a large number of molecules, in order to deduce a possible structure/property relationship.

The present work also showed that halogenated 2-phenylbenzoxazole derivatives deserve being considered for applications as solid-state blue emitters. In particular, the chlorinated derivative 2 could be an interesting candidate, combining an acceptable photoluminescence quantum yield with a tendency to give flat, elongated particles that could find a utility in microdevices.

\section{Acknowledgments}

We are very grateful to Ms Elise Murat for her help in preliminary work. We would also like to thank Mr. Stéphane Le Blond du Plouy (Service Commun de Microscopie Electronique de l'Institut de Chimie de Toulouse) and Ms Caroline Toppan (Service Commun de RMN de l'Institut de Chimie de Toulouse) for SEM and NMR measurements, respectively. Financial support from EuroNanoMed ERA-NET JTC2011 (FONDIAG project) is warmly acknowledged.

\section{References}

[1] Fery-Forgues S. Fluorescent organic nanocrystals and non-doped nanoparticles for biological applications. Nanoscale 2013;5:8428-42.

[2] Klymchenko AS. Emerging field of self-assembled fluorescent organic dye nanoparticles. J Nanosci Lett 2013;3:21.

[3] Jagannathan R, Irvin G, Blanton T, Jagannathan S. Organic nanoparticles: preparation, self-assembly, and properties. Adv Funct Mater 2006;16:747-53.

[4] Zhao YS, Fu H, Peng A, Ma Y, Xiao D, Yao J. Low-dimensional nanomaterials based on small organic molecules: preparation and optoelectronic properties. Adv Mater 2008;20:2859-76.

[5] Schiek M, Balzer F, Al-Shamery K, Brewer JR, Lützen A, Rubahn HG. Organic molecular nanotechnology. Small 2008;4:176-81.

[6] Patra A, Chandaluri ChG, Radhakrishnan TP. Optical materials based on molecular nanoparticles. Nanoscale 2012;4:343-59.

[7] Krasovitskii BM, Bolotin BM. Organic luminescent materials. Weinheim: VCH; 2002.

[8] Birks JB. Photophysics of aromatic molecules. London: Wiley; 1970.

[9] Ghodbane A, D'Altério S, Saffon N, McClenaghan ND, Scarpantonio L, Jolinat P, et al. Facile access to highly fluorescent nanofibers and microcrystals via reprecipitation of 2-phenyl-benzoxazole derivatives. Langmuir 2012;28: 855-63.

[10] Ghodbane A, Colléaux J, Saffon N, Mahiou R, Galaup JP, Fery-Forgues S. Blueemitting nanocrystals, microcrystals and highly oriented nanofibers prepared via reprecipitation and solvent drop-casting in the 2-phenyl-naphthoxazole series. ChemPlusChem 2013;78:185-91.

[11] Fery-Forgues S, Paillous N. Photodehalogenation and photodimerization of 2(4-halophenyl)benzoxazoles. Dependence of the mechanism on the nature of the halogen atom. J Org Chem 1986;51:672-7.

[12] Paillous N, Fery-Forgues S, Jaud J, Devillers J. [2+2] Cycloaddition of two $C=N$ double bonds. First structural evidence for head-to-tail photodimerization in the 2-phenylbenzoxazole series. J Chem Soc Chem Commun 1987;8:578-9.

[13] Fery-Forgues S, Lavabre D, Paillous N. Electron transfer on the photodehalogenation of 2-(4-chlorophenyl)benzoxazole assisted by amines. J Org Chem 1987;52:3381-6.

[14] Valeur B. Molecular fluorescence, principles and applications. Weinheim: Wiley-VCH; 2002. p. 56.
[15] Postovskii IYa, Pushkina LN, Mazalov SA. Benzazoles. I. Syntheses of benzoxazoles for a study of their scintillating properties. Zhurnal Obshchei Khimi 1962;32:2617-24.

[16] Hong HW, Chen TM. Effect of substituents on the photoluminescent and electroluminescent properties of substituted cyclometalated iridium(III) complexes. Mater Chem Phys 2007;101:170-6.

[17] Chen TR. Synthesis and characterization of cyclometalated iridium(III) complexes containing benzoxazole derivatives and different ancillary ligands. J Org Chem 2008;693:3117-30.

[18] Hartley CD, Mordaunt JE, Shah P, Slater MJ. Preparation of heterobiarylphenyl thiophenecarboxylates as antivirals. PCT Int Appl. 2007, WO 2007088148 A1 20070809.

[19] Malakhova EV, Malakhov AD, Kuznitsova SV, Varnavskii OP, Kadutskii AP, Kozhich DT, et al. Reagents for introducing a fluorescent deoxyuridine 2phenylbenzoxazole derivative into oligonucleotides. Bioorg Khim 1998;24: 688-95.

[20] Yen FW. Phenanthroline derivatives and organic light-emitting devices using them. U.S. Pat. Appl. Publ. 2008, US 20080265746 A1 20081030.

[21] Seo S, Kawakami S, Nomura H, Ohsawa N. Organic semiconductor material and light-emitting element, light-emitting device, lighting system, and electronic device using the same. PCT Int. Appl. 2010, WO 2010027004 A1 20100311

[22] Ackermann L, Barfüsser S, Pospech J. Palladium-catalyzed direct arylations, alkenylations, and benzylations through $\mathrm{C}-\mathrm{H}$ bond cleavages with sulfamates or phosphates as electrophiles. Org Lett 2010;12:724-6.

[23] Marsden SP, McGonagle AE, McKeever-Abbas B. Catalytic aza-Wittig cyclizations for heteroaromatic synthesis. Org Lett 2008;10:2589-91.

[24] Guru MM, Ali MA, Punniyamurthy T. Copper(II)-catalyzed conversion of bisaryloxime ethers to 2-arylbenzoxazoles via $\mathrm{C}-\mathrm{H}$ functionalization/C-N/ C-O bonds formation. Org Lett 2011;13:1194-7.

[25] Saha P, Ramana T, Purkait N, Ali MA, Paul R, Punniyamurthy T. Ligand-free copper-catalyzed synthesis of substituted benzimidazoles, 2aminobenzimidazoles, 2-aminobenzothiazoles, and benzoxazoles. J Org Chem 2009; 74:8719-25.

[26] Sheldrick GM. A short history of SHELX. Acta Crystallogr A 2008;64:112-22.

27] Reiser A, Leyshon LJ, Saunders D, Mijovic MV, Bright A, Bogie J. Fluorescence of aromatic benzoxazole derivatives. J Am Chem Soc 1972;94:2414-21.

[28] Kubelka P, Munk PZ. Ein Beitrag zur Optik der Farbanstriche. Z für Tech Phys 1931;12:593-601.

[29] De Mello JC, Wittmann FH, Friend RH. An improved experimental determination of external photoluminescence quantum efficiency. Adv Mater 1997;9: 230-2.

[30] Roussilhe J, Paillous N. Etude par spectroscopie d'absorption et de fluorescence d'aryl-2 benzooxazoles : UV absorption and fluorescence spectroscopy of 2-aryl benzoxazoles. J Chim Phys Phys-Chim Biol 1983;80:595-601.

[31] Dey JK, Dogra SK. Absorption and fluorescence characteristics of some 2-alkyland 2-aryl-benzoxazoles in different solvents and at various acid concentrations. Indian J Chem 1990;29A:1153-64.

[32] Chou PT, Cooper WC, Clements JH, Studer SL, Chang CP. A comparative study. The photophysics of 2-phenylbenzoxazoles and 2-phenylbenzothiazoles. Chem Phys Lett 1993;216:300-4.

[33] Hilal R, Khalek AAA, Elroby SAK. Theoretical and experimental investigation of the electronic spectra of antitumor compounds. Spectroscopy 2005;20:42-53.

[34] Slater JC. Atomic radii in crystals. J Chem Phys 1964;41:3199-204.

[35] Rao PV, Murthy KS. Space group and unit cell dimensions of 2-phenyl benzoxazole. Curr Sci 1966;35:616-7.

[36] Ghosh D. Personal communication.

[37] Cornil J, Beljonne D, Dos Santos DA, Calbert JP, Shuai Z, Brédas JL. A theoretical insight into the solid-state optical properties of luminescent materials: the supermolecular approach. Comptes Rendus l'Académie Sci Paris 2000;(IV): 403-8.

[38] Xie Z, Yang B, Li F, Cheng G, Liu L, Yang G, et al. Cross dipole stacking in the crystal of distyrylbenzene derivative: the approach toward high solid-state luminescence efficiency. J Am Chem Soc 2005;127:14152-3.

[39] Nakanishi H, Oikawa H. Reprecipitation method for organic nanocrystals. In: Masuhara H, Nakanishi H, Sasaki K, editors. Single organic nanoparticles. Berlin: Springer-Verlag; 2003. p. 17-31 [chapter 2].

[40] Kasai H, Nalwa HS, Oikawa H, Okada S, Matsuda H, Minami N, et al. A novel preparation method of organic microcrystals. Jpn J Appl Phys 1992;31: L1132-4.

[41] Bîrlă L, Bertorelle F, Rodrigues F, Badré S, Pansu R, Fery-Forgues S. Effects of DNA on the growth and optical properties of luminescent organic microcrystals. Langmuir 2006;22:6256-65.

[42] Mille M, Lamère JF, Rodrigues F, Fery-Forgues S. Spontaneous formation of fluorescent nanofibers from self-assembly of low-molecular-weight coumarin derivatives in water. Langmuir 2008;24:2671-9.

[43] Chahine J, Saffon N, Cantuel M, Fery-Forgues S. Spontaneous formation of fluorescent nanofibers and reticulated solid from berberine palmitate: a new example of aggregation-induced emission enhancement in organic ion pairs. Langmuir 2011;27:2844-53. 